\title{
Political Media Communication: Bilingual Strategies in the Pre-Election Campaign Speeches
}

\section{Tatyana Yu. Tameryan}

Faculty of Foreign Languages, North-Ossetian State University named after K.L. Khetagurov, Vladikavkaz, RUSSIA

(1) 0000-0001-9576-8386 L-1756-2018

\section{Marina R. Zheltukhina}

Institute of Foreign Languages, Volgograd State Socio-Pedagogical University, Volgograd, RUSSIA (iD) 0000-0001-7680-4003 SC 56669701900 A-7301-2015

zzmr@mail.ru

\section{Gennady G. Slyshkin}

Centre of Linguistics and Professional Communication, Russian Presidential Academy of National Economy and Public Administration, Moscow, RUSSIA

(iD) 0000-0001-8121-0250 SC 57191286505 G G-1470-2014

\section{Larisa L. Zelenskaya}

School of Governance and Politics, Moscow State Institute of International Relations (University) of the Ministry of Foreign Affairs Russian Federation (MGIMO-University), Moscow, RUSSIA

(iD) 0000-0002-7349-4027 D D-7075-2019

\section{Olga P. Ryabko}

Institute of Philology, Journalism and Intercultural Communications, Southern Federal University, Rostov-on-Don, RUSSIA

(D) 0000-0002-8505-6307 SC 57205248493 J-6826-2017

\section{Marina A. Bodony}

Faculty of Romance and Germanic Philology, Kuban State University, Krasnodar, RUSSIA

(iD) 0000-0002-1182-0587

\section{ARTICLE INFO}

Received: 23 February 2019

Accepted: 11 June 2019

Published: 4 August 2019

DOI: https://doi.org/10.29333/ojcmt/5869

ABSTRACT

This article concerns the research of such new aspect of political media communication as bilingualism in the young state of South Ossetia' election campaign. The study is devoted to the description of tactical and strategic tools of candidates for the presidency of the country in 2017. The strategic use of the Ossetian and Russian language systems, determined by the intentions of presidential candidates, the target audience, and the communicative situation, characterizes the language identities of Ossetian politicians as ambilingists switching easily between the two codes. The study shows that selfpresentation is one of the dominant strategies, as candidates seek to present themselves as the most worthy candidate for the presidency, using a specific set of language means and speech constructs. As the language analysis of the pre-election speeches testifies, the ethnic identity of the newly emerged South Ossetian political media communication is characterized by the development of mechanisms for dialogical interaction based on the 
rejection of the opposability of the leaders of the branches of government in the mass media.

The authors state that the main characteristics of electoral meetings with voters and debates represent ritual actions that are part of the traditional Ossetian communication scenario. The role-playing behavior of the participants in the presidential election also reflects the specifics of interaction between the senior and junior. Special discourse signs are the principles of openness and feedback that have been most effective as dominant strategies. The study of the texts of the candidates' speeches by the candidates is the orientation of the presidential candidates to various segments of society, united according to the family-patronymic, territorial and socio-political principles. Thus, the tactical and strategic complex of this election campaign is based on a self-presentation strategy implemented by the tactics of identification and demonstration of ethnicity.

Keywords: South Ossetian political media discourse, politician's communicative image, speech strategies, bilingual strategies, self-presentation techniques, ritual communication, traditional scenario

\section{INTRODUCTION}

Insufficient study of the pre-election political media discourse in South Ossetia which combines the features of the institutional/half-institutional and ritual communication, the need for systematizing the data on the strategies, tactics and tactical means of influence the voters in order to form social consciousness - all these factors determine the relevance of this article and confirm the significance of the research, with the aim of elicitation and describing universal and ethno-specific features of the political world in the language picture of the political world of citizens in South Ossetia.

Political discourse as a basic concept of linguistics along with political linguistics has recently become a subject of scientific study and comprehension. The development of political linguistics is regarded in close connection with such linguistic disciplines as media linguistics, communicative and cognitive linguistics, pragmalinguistics and paralinguistics.

\section{LITERATURE REVIEW}

The study of political discourse is based on the premise of the general theory of discourse developed by both foreign linguists and Russian linguists (Chilton, 2004; Dijk van, 1997; Franssila, 2013; Sheigal, 2000; Tameryan et al., 2018a, 2018b, 2019; Volskaya et al., 2018; Zheltukhina et al., 2019, etc.).

There are six basic approaches to the study of political linguistics identified within the boundaries of the general theory of communication: 1) system, 2) linguistic, 3) symbolic, 4) functional, 5) organizational, 6) environmental (Meadow, 1980, p. 24).

The linguistic research suggests two approaches to the study of political communication they are descriptive and critical (Chilton, 1994, 2004; Sheigal, 2000, etc.). The descriptive approach in modern linguistics involves the analysis of the linguistic portrait of political communication participants, i.e. linguistic means, strategies and tactics used by politicians, in addition to the analysis of the content aspect of political texts from the standpoint of their conceptual and ideological representation (Chilton \& Ilyin, 1993; Jemieson, Campbell, 1997; Pfau et al., 1990; Stuckey, Antczak, 1995; Thomson, 1977, etc.).

The critical approach is based on the study of social inequality which has received linguistic expression in the discourse. This perspective focuses on the description of 
language as a means of power and social control (Lassan, 1995; Wodak, 1994; van Dijk, 1988 , etc.).

The cognitive approach to the study of political discourse as the most effective method of political linguistics allows us to move from the description of units and structures to the modeling of structures of consciousness of communicants those of frames, scenarios, concepts and metaphorical models of political communication (Chilton \& Ilyin, 1993; Franssila, 2013; Lassan, 1995; van Dijk, 1997, etc.).

The language of political communication is influenced by the content of the transmitted information, which is determined by the circumstances of its realization and specific political objectives of communicants (Graber, 1981, p. 196).

One can proceed from either a broad or a narrow approach to the definition of political discourse. A broad approach to the content of the concept of "political discourse" is based on its interpretation as a set of speech acts used in political discussions, as well as a system of rules of public policy sanctified by tradition and proved by experience (Baranov \& Kazakevich, 1991, p. 6). In a narrow sense political discourse is limited by the institutionality of communication and is interpreted as a class of genres (van Dijk, 1995).

Achievements of media linguists consist in developments of linguistic and cognitive, linguistic and pragmatic approaches to studying of influence in media communication (Aleshchanova et al., 2018; Tameryan et al., 2018a, 2018b, 2019; Volskaya et al., 2018; Zheltukhina et al., 2019).

The main system-forming goal of political media discourse is the struggle for power which serves as a determining factor in the choice of a strategic arsenal of communicative actions in the political media communication which are based on the desire to influence the intellectual, volitional and emotional sphere of the addressee. The pragmatics of this function is realized through the choice of certain speech strategies, tactics and tactical moves.

In our research the complex methods of semantic, functional, pragmatic, and interpretative analysis of the pre-election campaign speeches in the South Ossetian political media discourse are used. The results of analysis are useful for pragmalinguistics, socio- and psycholinguistics, lexicology, semantics, stylistics, discourse linguistics, media and political linguistics, cultural linguistics.

\section{RESULTS AND DISCUSSION}

Ethno-cultural specificity of political media discourse construction is connected with the peculiarities of speech activity, language picture of the world formed in the language consciousness of the people. The specific features of political media communication convey the individual characteristics of mentality, social conditions that determine the implementation of political communication. One of the important conditions for the study of ethno-specific characteristics of political discourse is to identify the relevant features of culture which are represented by the participants of political media communication, implemented through a set of strategies and tactics in mass media.

The strategy of self-presentation is a key in modeling a positive image of a politician. General regularities of forming political media communication of presidential candidates implemented through a number of tactics and communication moves. One tactic is to identify oneself with certain groups in society.

The concept of self-presentation comes from the English "self presentation", that is the representation of yourself to others. In the English encyclopedic dictionary it is literally 
T. Y. Tameryan, et al.

characterized as "the process of strategically conceiving or revealing personal information in order to influence others' perceptions" (Oxford English Dictionary OED http://www.oed.com/).

The scripts of video recordings of meetings with voters along with the rounds of election debates, public speeches, texts of election programs and interviews with the participants of the elections for President of the Republic of South Ossetia (A.I. Bibilov, L.H. Tibilov, A.E. Gagloev) have served as the material for the study of the strategic identity of the participants of the pre-election political media communication in 2017.

We have analyzed 3,500 text fragments and identified 15 types of communication strategies from: a self-presentation strategy, a manipulative strategy, a feedback strategy, a unity strategy, a discredit strategy, a self-defense strategy, an interpretative strategy, an addressee's emotional attitude strategy, an argumentative strategy, an agitation strategy of heroization, a persuasion strategy, strategies of openness of power, strategy of opposition, strategy of personification of power.

The strategy of self-presentation is implemented through identification tactics in 530 media text fragments. This is $70.2 \%$ of the total number of tactics implementing this strategy. The tactics of positive positioning can be traced in text fragments, which is $12.6 \%$ of the total number of tactics. The tactic of solidarity with the addressee is $7.2 \%$. The tactic of communicative variation is represented by $6.4 \%$. Tactic support found implementation 2.8\%. $1.37 \%$. Tactic of ridicule is used $0.8 \%$.

We have identified 570 fragments of the use of bilingual strategies in political media communication in the incarnation of the Speaker of Parliament. The analysis of the language situation made it possible to trace the peculiarities of the choice of a language by a politician according to the specific communicative situation and to determine his strategic orientations, which are realized in both ethnic and social variability of certain groups of the population of the Republic.

For the majority of the population of the RSO, especially those who had studied or worked in the territory of the Russian Federation, the Russian language has become the second native one, thus their vocabularies have mixed into a single one. The study of speech behavior of presidential candidates is conducted within the framework of linguistic pragmatics, according to which the meaning of expression is formed according to the specific communicative situation. The functional distribution of Russian and native languages depends directly on the type of the target audience. The presence of domestic bilingualism in the speech of South Ossetian politicians is a means of influencing the audience (Ayoun, 1999; Luk, 2014; Vallan, 2014)

The purpose of the wedging of words in the ethnic language into the prepared speech in Russian is to influence the target audience and represents a manipulative communicative strategy. The mixed bilingualism is more likely to occur if a politician uses two languages in communicative objectives in the same situation. In this case a new connection is formed between the two speech mechanisms related to the generation of multilingual speech (Ikizer \& Ramirez-Esparza, 2017; Toribio, 2001).

The political media communication in South Ossetia is performed both in Russian and Kudar dialect of the Ossetian language. The office work is conducted in both the Russian and Ossetian languages. The South Ossetian political media discourse, especially parliamentary and presidential, is developing on the model of Russian political media discourse. Communication within the framework of institutional discourse is carried out in Russian. Cases of interference or intercalation are observed in the speaker's 
unprepared speech at meetings with various groups of the population within the framework of semi-institutional discourse (rural population, professional groups).

The candidates for the post of President of South Ossetia, purposefully pursuing the idea of ethnic identification, use the Kudar dialect of the Ossetian language, which is spoken by the majority of the population of the Republic. Through the practice of forming political media communication in the dialect of the great amount of people in the RSO, the candidates implement the tactics of identifying the political figure with the citizens who make up the potential electorate.

The analysis of the materials of election meetings, which chronologically as a rule precede the debate, suggests that the bilingualism of candidates and the electorate should be a tool that allows them to influence the formation of public opinion, to gain the trust of the electorate.

The high frequency of switching language codes, interference, intercalation, macaronic speech characterize the political media discourse of all three candidates and are the main features of communication in the framework of pre-election meetings with voters and preelection debates.

The study of texts of speeches, meetings, appeals of candidates for the post of President of South Ossetia shows that communication at the highest national/international levels, and formal contacts are made in Russian.

The choice of the language in the speeches addressed the electorate, represented by the citizens of the RSO and the RSO-Alania, who speak both languages (Ossetian and Russian), representatives of Ossetian diasporas from different countries within the framework of institutional discourse is determined by the goals and strategies of communication.

The language systems of both languages are often intertwined in candidates' speeches and interviews. More often delivering a speech in Russian a candidate switches to his native language, inserting a word or expression, and ends the thought according to the rules of Russian grammar. Thus, he exposes elements of the native language to the norms of the Russian language. We are talking about the unprepared speech at the meetings with the population in the conditions of semi-institutional discourse, and sometimes at meetings of Parliament when discussing the most urgent problems.

There is a great number of international terms in the South Ossetian political media discourse of modern times. The Russian language is the main source of borrowings, the terminology was also formed by borrowing international units that had come to the Ossetian language through Russian.

Socio-cultural space transformed into certain views, norms, standards of behavior, forming components of his worldview, worldview, worldview and coding of the results of human cognitive activity acts in the human consciousness. In such a way the transformations in the lexical composition of the language occur in the schemes of direct speech communication and other linguistic means that implement the cultural and ideological intentions of a certain social group, class, nation, culture. The accumulation period of the Ossetian political vocabulary in the seventies - eighties of the $20^{\text {th }}$ century has developed a number of methods of derivation from Russian borrowings, demonstrating the internal cognitive mechanisms of adaptation of loanwords in the Ossetian language. For instance, the suffix of the adjectives -on (administrative administrativon; party - partion); ending of the borrowings into native suffix of the plural nouns -tæ (MPs - deputattæ; regulations - normætæ); Ossetian suffixes of the abstract 
nouns -ad (legislation - zakondjttinad) and -dzinad (law - zakondzinad). Moreover, the methods of translation from Russian into Ossetian are widely used (the first half - ficcag ærdæg) along with lexical intercalation (five-year plan - fondzazon plan).

The analysis of the language situation allows us to trace the features of the choice of communication language by politicians according to the specific communicative situation and to determine its strategic orientation, implemented in the ethnic and social variability of certain groups of the population of the Republic. The candidates for the post of President of the RSO resort to the ethnic language if speaking to the Ossetian-speaking electorate, presenting the course of the language policy of the state, appealing to the civil and ethnic identity of Ossets. During the speeches to the mixed ethnic electorate, ambilingua candidates who coordinately speak languages, switch to the Russian language, which is spoken by the majority of the population of the Republic. The use of both Russian and Ossetian emphasizes the inseparable commonality of the two peoples the Russians and the Ossets.

A. Bibilov thanked the children for the celebration of peace and prosperity, at one of the school events dedicated to the victory day in the Great Patriotic war:

Mahæn ta næ sombon_aci ræsugd sombon ci nikui ual fena hæst_æmæ ali hatt dær sabirdzinadi ci cæroi_ci kusoi_ci arhaioi_uici amond radtæt Huicau. Æmæ mænæ plakatil fedton ahæm nihæstæ..- "I wish everyone happiness in the future! God knows that we all want to live and work under the peaceful sky": "The veterans leave, the victory remains!". I would like to keep the memory of the veterans in our hearts. And the victory is for us! (Parliament of the Republic of South Ossetia. www.parliamentrso.org). In the given fragment the Ossetian language prevails, while the inserts in Russian demonstrate the commonality of the historical homeland and the proximity of the peoples of Russia and South Ossetia:

The pre-election meeting of the candidate L. Tibilov with the citizens of RSO who live in the territory of the Republic of North Ossetia-Alania was held mainly in the Ossetian language, as the cultural and linguistic identity is one of the leading categories within the framework of the total identity formed in the minds of ethnic Ossets:

Fændi mæ banisan kænin_ cidæriddær Hussar Iristoni aræztæui_uii u Uæræseii Federaciii æhhuisi færci. Vladimir Putinimæ næ fembældi æz fehuiston nifsi nihæstæ_ uici æhhuis nin darddær dær kæi cæudzæn. Ting ahsdjiag u_uici æhhuis binatil æmbælin kæi raididta_æmæ respublikæii cidær_tæ kæi fæzind (Vyacheslav Bitarov "How South Ossetia is reborn". http://new.xurzarin.ru/bitarty-vyacheslav-xussar-iryston-kuydaendidzy-uymaen-aenaefengae-naej/). I would like to admit that everything what is being done in South Ossetia is being done with the help of the Russian Federation. At the meeting with Vladimir Putin, I had received assurances that this assistance will be continued. It is very important for it to reach its aim, something new has appeared in the Republic (Leonid Tibilov vstretilsya s grajdanami $\mathrm{RYuO}_{-}$projivayuschimi v Severnoi Osetii / Leonid Tibilov met with citizens of the RSO living in North Ossetia. http://osinform.org/60587-leonid-tibilov-vstretilsya-s-grazhdanami-ryuoprozhivayuschimi-v-severnoy-osetii.html).

The method of mixing language codes, valid only in the conversational register of communication, marks the strategy of identification of power and people: («I am like you / I am one of you»).

Thus, in the dialogue between the communication objects submitted by the candidate A. Tibilov and his confidant, objectified the idea of moral characteristics of A. Gagloev and 
the implementation of his ethnic status of the young, has contributed his time out of respect for the elder member communication.

A. Bibilov: Alan_ cæmæi iæ zonai_Verhovni sudi tærhontæ Konstitucionni sudmæ irvitæn næi. Uidon Konstitucionni sudmæ næ hauinc. A. Gagloev: Æmæ sæ æz dær uirdæm næ 'rvitin. A. Bibilov: "Alan, just for you to know that the Supreme Court decisions are not passed to the Constitutional Court. They do not belong to the Constitutional Court". A. Gagloev: "And I do not pass them there".

Political media communication in the Republic of South Ossetia is developing in the traditions of national culture based on the structural features of the Russian political media discourse. The peculiarities of tactical and strategic pragmatics in the national political discourse can be generated by the ethno-cultural tradition of a certain state. Each political culture forms a unique ethnic segment that embodies historical experience, political values and orientations in the ethno-specific format of political behavior.

Ritualism is a leading feature of South Ossetian political media communication, which is based on the fixation of existing ethnic scenarios of communication, social roles, rules and regulations.

The strategy of self-presentation used by the candidates for President of the RSO formed the strategic core of this election campaign allowing each of the participants to carry out positive positioning through dominant tactics of identification and demonstration of ethnicity.

The analysis showed that communicative strategy of self-presentation of the candidates for the post of the President is implemented by the most frequent "I" and "We" models: "I am a citizen of South Ossetia"/ the Chairman of the party "United Ossetia"/ the Chairman of the Parliament of the RSO/ President / Osset/ the elder/ the young; We are citizens of the RSO/members of the party "United Ossetia"/ MPs/ leadership.

At the time of the presidential campaign A. Tibilov, being the President of the RSO, put forward his candidacy to participate in the elections:

I, as the head of the state, demand that all branches of government should work on the tasks that face us<...> (Interview to the TV channel "Russia 24". http://presidentruo.org/intervyu-telekanalu-rossiya-24-5/);

And I as the acting President was obliged to get this chance and to give our people the opportunity to return the ancient name of our state-Alania, while maintaining the name - the Republic of South Ossetia. Elections in South Ossetia (Tibilov goes under the slogan "Alania forward." https://eadaily.com/ru/news/2017/03/15/vybory-v-yuzhnoy-osetiitibilov-idet-pod-lozungom-alaniya-vpered).

Today we have chosen this form of communication (Interview to the TV channel "Russia 24". http://presidentruo.org/intervyu-telekanalu-rossiya-24-5/). This model assumes "I am inclusive", because L. Tibilov speaks about himself as a representative of the country's leadership.

We have survived and won (Leonid Tibilov. Pre-election program. http://www.nykhas.ru/293382/leonid-tibilov-predvybornaya-program/). "We" model identifies the candidate with the people of South Ossetia, with all the citizens of the Republic fighting for their independence.

The main ideological emphasis in L. Tibilov's pre-election speeches was put on social harmony and unity of the people, renewal of the system of state administration, implementation of the principle "power for the people, not the people for the power", 
increasing the level of social guarantees and protection, economic development, security and stability. Using the pronoun "we", the politician implements the tactics of solidarity with his citizens.

The tactics of demonstrating ethnicity is implemented in the following text fragments: "Dear citizens of South Ossetia, Alans $<\ldots>$; <...> residents of South Ossetia<...>". (Parliament of the Republic of South Ossetia. http://presidentruo.org/obrashhenie-knarodu-respubliki-yuzhnaya-osetiya-6/).

Multiple uses of personal deixis, ethnonyms, and epistemic words implement the tactics of demonstrating their ethnic index, serving the communicative purpose to inspire people to new achievements, to return the name of glorious ancestors. The idea of renaming the state and returning the historical name shifts the pathos of the candidate to a qualitatively higher level, taking shape as the main ideological direction in the development of the country.

Expressing his views on his nomination for a second term, Leonid Tibilov has resorted to an illeistic self-reference by the transposition from the first person singular to the third person singular (acting President; he has managed many things; the President is workable). Resorting to this method of political rhetoric, the candidate assumes that, despite the constitutional right to run for a second term, only a positive assessment of the effectiveness of his activities as head of state is decisive.

A. Bibilov was nominated as a candidate for President from the party "United Ossetia" being both the Chairman of the party and the speaker of the Parliament. The models of personal deixis singular and plural in the discourse of the politician represent him as a citizen of the RSO, the Chairman of the Parliament, the Chairman of the political party "United Ossetia" and its ideological inspirer. However, the most recurrent component is the Chairman of the political party "United Ossetia".

There are types of models that conduct a communicative strategy of self-presentation using the tactics of identification with the citizens of the Republic, the people of South Ossetia, members of the Parliament in the following fragment:

$<\ldots>$ I, as a citizen of the Republic, as the Chairman of the Parliament, as the Chairman of the political party "United Ossetia" do not agree with the wording of the question. In our promises and statements, we made it clear to the people that if we hold a referendum, the only question will be: "Do we want to join the Russian Federation?"- an absolutely clear, an absolutely precise and an absolutely unambiguous question $<\ldots>$ ( Parliament of the Republic of South Ossetia. www.parliamentrso/org).

The strategy of self-presentation is implemented by the tactics of identification, positive positioning, explanation, statement of questions.

The purpose of using the communicative strategy of self - presentation is to create a positive image against the background of political opponents in the person of the acting President and his team.

The desire to make a favorable impression on the audience in order to "earn political points" is clearly expressed in the speaker's speeches. A. Bibilov uses the tactics of positive positioning through interaction with all structures and obtaining results to implement the communicative strategy of self-presentation. The orator demonstrates his willingness to work for the people in close cooperation with the executive branch. The anaphoric "I want/ we want" constructions reinforce the impact on the listener, demonstrating the positive potential of the presidential candidate: 
$<\ldots>$ I just want to work, I want the Parliament to work $<$... $>$ (Echo of the Caucasus. http://www.ekhokavkaza.mobi); We want to work, we want to interact (Parliament of the Republic of South Ossetia www.parliamentrso/org).

The peculiarities of tactical and strategic pragmatics in the national political media discourse can be generated by the ethno-cultural tradition of a certain state. Each political culture forms a unique ethnic segment that embodies historical experience, political values and orientations in the ethno-specific format of political behavior.

Ritualism is a leading feature of South Ossetian political media communication, which is based on the fixation of existing ethnic scenarios of communication, social roles, rules and regulations.

\section{CONCLUSION}

The analysis made allows to conclude about the general bilingual nature of the political media communication of the Republic with the observed shift of language priorities in favor of the Ossetian language in domestic communication (in business and household spheres) and the dominance of Russian at the interstate and international level of contacts.

The South Ossetian discourse should be characterized by a specific implementation of the conceptual link "people - power", which is based on the ethnic traditions of community, liberal-democratic collegiality and status, social and age hierarchy. Purposefully pursuing the idea of ethnic and social identification, the candidates for the post of President of South Africa implement the tactics of identifying the political figure with the citizens who make up the potential electorate.

The scenario of pre-election meetings and debates is based on the principle of role distribution, in order to show the integration of an individual member of society in a certain political, social and territorial segment, high value significance of belonging to their group.

The study of the texts of speeches, meetings, appeals of candidates for President of the RSO shows that the tactical and strategic arsenal of the contenders serves the implementation of the discourse of power and people. The lack of distance between the government and the people determines the confidence modality and ensures the productivity of the discourse of South Ossetian politicians.

Communicative personality of the candidates for President of South Ossetia L. Tibilov, A. Bibilov and A. Gagloev have implemented the strategy of self-presentation, guided by the ideology of unity with the people of the Republic.

\section{ACKNOWLEDGEMENT}

The reported study was funded by RFBR and MES RSO according to the research project № 19-512-07002 (10-МК/19).

\section{REFERENCES}

Aleshchanova, I. V., Frolova, N. A., \& Zheltukhina, M. R. (2018). Evolution of Motives in Professional Personality Formation: Foreign Language Learning Context. In: Proceedings of the International Conference on the Theory and Practice of Personality Formation in Modern Society (Ictppfms 2018), 198, 35-40. 
T. Y. Tameryan, et al.

Ayoun, D. (1999). Bilingualism and the "Mixed Language" Phenomenon. Published online by Cambridge University Press: 01.12.1999, pp. 187-189. https://doi.org/10.1017/S1366728999210310

Baranov, A. N., \& Kazakevich, E. G. (1991). Parliamentary Debates: Traditions and Innovations. Moscow: Knowledge. $64 \mathrm{p}$.

Bitarov, V. (2017). How South Ossetia is reborn. Retrieved from http://new.xurzarin.ru/bitarty-vyacheslav-xussar-iryston-kuyd-aendidzy-uymaenaenaefeng

Chilton, P. (1994). Politics and Language. In R. E. Asher (ed.), The Encyclopedia of Language and Linguistics (6th ed.) (pp. 3215-3221). Oxford: Pergamon Press.

Chilton, P. (2004). Analysing Political Discourse: Theory and Practice. NewYork: Routledge. https://doi.org/10.4324/9780203561218

Chilton, P., \& Ilyin, M. (1993). Metaphor in Political Discourse: The Case of the 'Common European House. In Discourse \& Society (pp. 7-32). https://doi.org/10.1177/0957926593004001002

Dijk van, T. A. (1988). News as Discourse. New Jersey: Lawrence Elbbaum Assoc. Publ.

Dijk van, T. A. (1995). Ideological Discourse Analysis. In New Courant (pp.135-161). Helsinki: English Dept. University of Helsinki.

Dijk, van T. (1997). Discourse as Structure and Process: Discourse Studies a Multidisciplinary Introduction. SAGE Publication Ltd.

Echo of the Caucasus. (n.d.). Retrieved from http://www.ekhokavkaza.mobi

EurAsia Daily. (March 15, 2017). Elections in South Ossetia: Tibilov goes under the slogan "Alania forward." Retrieved from https:/leadaily.com/ru/news/2017/03/15/vybory-vyuzhnoy-osetii-tibilov-idet-pod-lozungom-alaniya-vpered

Franssila, S. (2013). Sell Metaphor in American Political News Discourse. Social and Behavioral Sciences, 95, 418-424. https://doi.org/10.1016/j.sbspro.2013.10.664

Graber, D. A. (1981). Political languages. In D. D. Nimmo, \& K. R. Sanders (eds). Handbook of Political Communication (pp. 195-223).

Ikizer, E. G., \& Ramirez-Esparza, N. (2017). Bilinguals' Social Flexibility. Published online by Cambridge University Press: 25.09.2017, pp. 957-969. https://doi.org/10.1017/S1366728917000414

Jamieson, K. H., \& Campbell, K. K. (1997). The Interplay of Influence: News, Advertising, Politics and Mass Media. Belmont, Ca: Wadsworth Publishing Company.

Lassan, E. (1995). Discourse of Power in the USSR: Cognitive-Discursive Analysis. Vilnus, $232 \mathrm{p}$.

Luk, G. (2014). Who are the Bilinguals (and Monolinguals)? Published online by Cambridge University Press: 14.10.2014, pp. 35-36. https://doi.org/10.1017/S1366728914000625

Meadow, R. G. (1980). Politics as Communication. Ablex Publishing Corporation. 269 p.

Oxford English Dictionary. OED. (n.d.). Retrieved from http://www.oed.com/

Parliament of the Republic of South Ossetia. (n.d.). Retrieved from http://www.parliamentrso/org

Pfau, M., Kenski, G., \& Nitz, M. (1990). Efficacy of Inoculation Strategies In Promoting Resistance To Political Attack Messages: Application to Direct Mail. Communication Monographs, 57(1), 25-43. https://doi.org/10.1080/03637759009376183

President of the Republic of South Ossetia. (March 22, 2017). Interview to the TV channel "Russia 24". Retrieved from http://presidentruo.org/intervyu-telekanalu-rossiya-24$5 /$ 
Online Journal of Communication and Media Technologies, 2019

Sheigal, E. I. (2000). Semiotics of political discourse. Volgograd: Peremena. 386 p.

Stuckey, M., \& Antczak, F. (1995). Issues and Images: the problem of Identification. Strategic Communication problems in presidential Campaigns. Communication Quarterly, 42(2), 120-133. https://doi.org/10.1080/01463379409369921

Tameryan, T. Yu., Zheltukhina, M. R., Sidorova, I. G., \& Shishkina, E. V. (2019). Stereotype Component in the Structure of Ethnocultural Archetype (On InternetBlogs). The European Proceedings of Social \& Behavioural Sciences, 200, 1716-1722. https://doi.org/10.15405/epsbs.2019.03.02.200

Tameryan, T. Yu., Zheltukhina, M. R., Slyshkin, G. G., Abakumova, O. B., Volskaya, N. N., \& Nikolaeva, A. V. (2018a). Metaphor in Political Media Discourse: Mental Political Leader Portrait. Online Journal of Communication and Media Technologies, 8(4), 377-384. https://doi.org/10.12973/ojcmt/3958

Tameryan, T. Yu., Zheltukhina, M. R., Slyshkin, G. G., Shevchenko, A. V., Katermina, V. V., \& Sausheva, Ye. V. (2018b). New Country's Political Discourse: Formation of Speech Technologies. Modern Journal of Language Teaching Methods, 8(7), 151-160.

The pre-election video of Alan Gagloeva from 04.02.17. https://www.youtube.com/watch?v=BY6OlHYqwU0

Thomson, O. (1977). Mass Persuasion in History: An Historical Analysis of the Development of Propaganda Techniques. Edinburgh: Paul Harris Publishing.

Tibilov, L. (2017). Pre-election program. Retrieved from http://www.nykhas.ru/293382/leonid-tibilov-predvybornaya-program/

Tibilov, L. (March 26, 2017). Leonid Tibilov met with citizens of the RSO living in North Ossetia. Retrieved from http://osinform.org/60587-leonid-tibilov-vstretilsya-sgrazhdanami-ryuo-prozhivayuschimi-v-severnoy-osetii.html

Toribio, A. J. (2001). On the Emergence of Bilingual Code-Switching Competence. Published online by Cambridge University Press: 17.12.2001, pp. 203-231. https://doi.org/10.1017/S1366728901000414

Vallan, V. (2014). Bilingualism and cognition. Published online by Cambridge University Press, 27.11.2014, pp. 3-24. https://doi.org/10.1017/S1366728914000522

Volskaya, N. N., Tameryan, T. Yu., Zheltukhina, M. R., Boeva-Omelechko, N. B., Komleva, L. A., \& Knyazeva, Ye. G. (2018). Literary Translation as Cognitive Overlap between Foreign and Native Languages. Modern Journal of Language Teaching Methods, 8(7), 161-172.

Wilson, G. D. (1990). Ideology and Humor Preferences. International Political Science Review, 11(4), 461-472. https://doi.org/10.1177/019251219001100404

Wodak, R. (1994). Critical linguistics and Critical Discourse Analisys. In Handbook of Pragmatics (pp. 1-24). https://doi.org/10.1075/hop.10.cri1

Zheltukhina, M. R., Bondareva, N. V., Zelenskaya, L. L., Anikeeva, I. G., Malygina, L. E. \& Chistyakov, A. V. (2019). Media Promotion Role of Economic Vocabulary: Specific Features and Functions in Presentation and Advertisement. Online Journal of Communication and Media Technologies, 9(2), e201907. https://doi.org/10.29333/ojcmt/5733

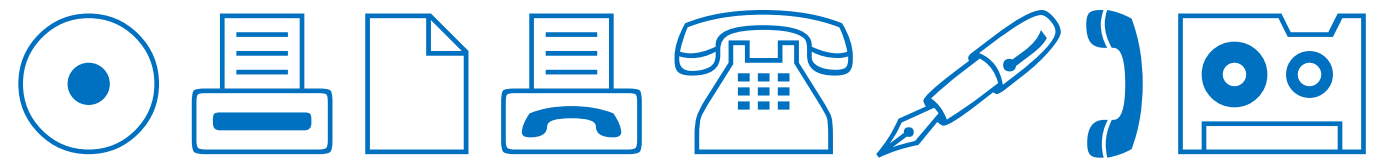

